\title{
Nota Científica \\ Efeito da fonte de carbono na embriogênese somática em Bactris gasipaes
}

\author{
Gisela Manuela de França Bettencourt ${ }^{1}$,Laudiane Bruna Zanella1', Marguerite Germaine Ghislaine Quoirin¹, Juliana Degenhardt-Goldbach²* \\ ${ }^{1}$ Universidade Federal do Paraná, Av. Coronel Francisco Heráclito dos Santos, s/n, CEP 81530-900, Curitiba, PR, Brasil \\ Embrapa Florestas, Estrada da Ribeira, Km 111, C P 319, CEP 83000-000, Colombo, PR, Brasil
}

*Autor correspondente:
juliana.degenhardt@embrapa.br
Termos para indexação:
Camada fina de células
Glicose
Sacarose
Index terms:
Thin cell layer
Glucose
Sucrose
Histórico do artigo:
Recebido em $22 / 10 / 2014$
Aprovado em $23 / 05 / 2016$
Publicado em $30 / 06 / 2016$
doi: $10.4336 / 2016 . p f b .36 .86 .809$

\begin{abstract}
Resumo - A metodologia de camada fina de células foi utilizada com sucesso para indução de embriogênese somática em região do meristema apical de plantas de pupunha mantidas em casa-de-vegetação. $\mathrm{O}$ efeito de três fontes de carbono: sacarose, glicose e manitol na indução de embriogênese somática foi avaliado. Embriões somáticos foram observados após a indução apenas nos meios contendo sacarose ou glicose em igual proporção.
\end{abstract}

\section{Effect of carbon source on somatic embryogenesis of Bactris gasipaes}

A pupunha é a única palmeira neotrópica domesticada (Silva \& Clement, 2005). Na culinária brasileira, o uso de palmitos extraídos de seu caule vem ganhando cada vez mais destaque e seu fruto é popular em sua área de distribuição natural na Amazônia. Esta espécie apresenta vantagens sobre outras palmeiras muito apreciadas, como Euterpe edulis. Ao contrário desta, Bactris gasipaes apresenta produção precoce $(1,5$ ano) e a característica de perfilhar (Villachica, 1996), o que permite sua permanência em campo por até 15 anos.

Um dos principais gargalos de sua exploração é seu sistema de produção. Os plantios comerciais atualmente são implantados a partir de sementes, cuja qualidade e viabilidade normalmente são baixas. A maior parte das sementes são importadas do Peru, em condições inadequadas de transporte e desinfestação. Além disso, a pupunheira apresenta problemas na produção de sementes nas condições do sul do Brasil, onde a polinização é muitas vezes deficiente. Isso colabora para a formação de cachos com poucos frutos com sementes viáveis (Mora-Urpi, 1984). A produção partenocárpica de frutos vem sendo observada ao longo dos anos, diminuindo ainda mais a produção de sementes e não sendo possível suprir a demanda para a produção de mudas.

A espécie é alógama e a fixação dos ganhos genéticos através da reprodução assexuada é interessante, podendo ser útil em programas de melhoramento da espécie por possibilitar a clonagem de indivíduos superiores. Dentre os métodos de propagação vegetativa, a embriogênese somática vem merecendo destaque na última década e a otimização dos protocolos sugere que sua aplicação 
comercial está próxima. Protocolos para embriogênese somática de pupunheira vêm sendo desenvolvidos a partir de diferentes tecidos, como ápices caulinares de plântulas germinadas in vitro (Steinmacher et al., 2007c), inflorescências (Steinmacher et al., 2007a) e embriões zigóticos (Steinmacher et al., 2007b). Embora grandes avanços tenham sido obtidos, a otimização dos protocolos ainda é necessária para viabilizar sua aplicação comercial.

Dentre os fatores que influenciam a rota morfogenética da embriogênese somática, a fonte de explante e seu estágio de desenvolvimento são determinantes para a alteração da competência celular (Merkle et al., 1995). O tamanho dos explantes também influencia a capacidade morfogênica (Benkirane et al., 2000; Delporte et al., 2001) e o emprego de explantes obtidos a partir de uma fina camada de células pode romper os domínios de comunicação intercelular existente nos tecidos, facilitando a entrada das células em divisão celular e a desdiferenciação celular. Com esse conceito, foi desenvolvida a técnica denominada TCL (Thin Cell Layer), que consiste na utilização de explantes de tamanho reduzido (Van \& Lê, 2000). Esta técnica foi utilizada previamente na indução de embriogênese somática em pupunha a partir de plântulas germinadas in vitro por Steinmacher et al. (2007c).

Além da influência do explante inicial, o meio de cultura influencia diretamente as respostas embriogênicas dos tecidos responsivos, sendo que a fonte de carbono exerce papel fundamental. A sacarose é normalmente o carboidrato utilizado na embriogênese somática em B. gasipaes (Steinmacher et al., 2007a, 2007b, 2007c).

A sacarose é um carboidrato com 12-C. Quando hidrolisado pela sacarose sintase ou invertase, libera uma molécula de glicose e uma de frutose, ambos com 6-C. O manitol, açúcar cujos grupos aldeído e cetonas foram reduzidos a álcool, é a forma reduzida da manose e é amplamente distribuído no reino vegetal (Buchanan et al., 2000).

Este trabalho teve por objetivo avaliar o efeito da fonte de carbono na formação de embriões somáticos a partir da região do meristema apical de plantas de Bactris gasipaes mantidas em casa-de-vegetação.

Foram mantidas 150 plantas de pupunheira com seis meses de idade em vasos na casa-de-vegetação da Embrapa Florestas, Colombo, PR. Em laboratório, as plantas tiveram suas folhas e raízes removidas para exposição dos ápices caulinares.
Os ápices caulinares foram mantidos sob água corrente por $3 \mathrm{~h}$, sendo posteriormente esterilizados em capela de fluxo laminar por imersão em solução de $1 \mathrm{~g} \mathrm{~L}^{-1}$ de fungicida (princípio ativo: metil tiofanato) por 10 min, seguida de imersão em $70 \%$ etanol por 1 min e finalmente $20 \mathrm{~min}$ em $5 \% \mathrm{NaOCl}$. Após a assepsia, os explantes foram lavados três vezes em água bidestilada autoclavada.

Após a remoção das bainhas foliares, com auxílio de um bisturi, a região do meristema apical foi cortada em cinco segmentos de $0,5 \mathrm{~mm}-1 \mathrm{~mm}$ (thin cell layers), desde a região do meristema apical até $1,5 \mathrm{~cm}$ além, no sentido superior. Os segmentos foram então inoculados em meio MS (Murashige \& Skoog, 1962) suplementado com vitaminas de Morel \& Wetmore (1951), $300 \mu \mathrm{M}$ de picloram, $500 \mathrm{mg} \mathrm{L}^{-1}$ glutamina, 1,5 $\mathrm{g} \mathrm{L}^{-1}$ de carvão ativado, $8 \mathrm{~g} \mathrm{~L}^{-1}$ de ágar e $30 \mathrm{~g} \mathrm{~L}^{-1}$ de sacarose, manitol ou glicose, para avaliar a indução de calos embriogênicos. Os calos não foram subcultivados até apresentarem aparência embriogênica. A maturação e a conversão dos embriões somáticos em plântulas foram realizadas conforme Steinmacher et al. (2007c).

$\mathrm{O} \mathrm{pH}$ de todos os meios foi ajustado para 5,8 antes da autoclavagem, realizada a $121^{\circ} \mathrm{C}$ por 15 min. Todas as etapas da cultura foram conduzidas no escuro a 23 $\pm 2{ }^{\circ} \mathrm{C}$. O experimento foi conduzido em delineamento inteiramente casualizado com 10 repetições de 4 explantes por tratamentos de diferentes carboidratos. Os dados foram submetidos à análise de variância e as médias dos tratamentos foram comparadas pelo teste $t$.

O processo de assepsia das plantas mantidas em casade-vegetação não foi eficiente, pois vários explantes foram perdidos por contaminação (variando de $28 \%$ no meio com glicose a $65 \%$ no meio com sacarose), a maioria por fungos, embora bactérias também tenham sido observadas.

Um mês após a indução, calos primários foram observados nos meios contendo sacarose e glicose. Quatro meses depois, foram observados calos com aspecto embriogênico nestes meios, caracterizando um processo indireto de formação de embriões somáticos. Em meio com manitol não foi observada a formação de calos. Após a transferência para meio de maturação, foram observados embriões somáticos (Figura 1). 


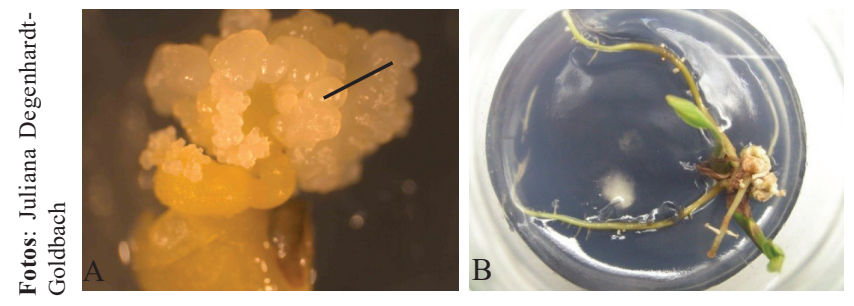

Figura 1. A. Aspecto de calo embriogênico de pupunha contendo embriões somáticos antes de repicagem para o meio de conversão; B. Planta de pupunha obtida por germinação de embrião somático em meio de cultura.

Normalmente, o processo de embriogênese somática consiste de duas etapas principais, a indução do processo e a expressão dos embriões resultantes dele (Jiménez, 2005). Teoricamente, este processo pode ser iniciado a partir de qualquer parte da planta. No entanto, diferenças substanciais na competência são vistas na prática. As células mais competentes para a embriogênese somática são geralmente aquelas vindas de tecidos jovens.

A fonte de carboidrato foi determinante na indução de calos embriogênicos de pupunha. A glicose foi tão eficiente quanto a sacarose na indução, sendo que um mês após a inoculação $60 \%( \pm 34,5)$ dos explantes saudáveis em meio com sacarose e 58,6\% $( \pm 18,7)$ dos explantes em meio com glicose haviam iniciado a formação de calos primários. No meio contendo manitol não foi observada a indução de calos.

Os primeiros calos embriogênicos apareceram cinco meses após o início do experimento, quando foram então trocados de meio de cultura pela primeira vez. Os resultados são semelhantes aos observados por Steinmacher et al. (2007c), que obtiveram $43 \%$ de calos embriogênicos em meio com sacarose.

A fonte de carboidrato foi testada para outras espécies e embora a maioria dos trabalhos utilize a sacarose, nem sempre este demonstrou ser o melhor carboidrato. Conforme Bensaad et al. (1996), em videira a sacarose produziu a maior formação de calos, seguida pela combinação de sacarose + manitol e de glicose e maltose, para a indução da embriogênese somática a partir de anteras.

No entanto, para esta mesma espécie, a formação de calos foi mais eficiente a partir de tecidos de frutos sem sementes nos meios suplementados com glucose + fructose e sorbitol em comparação com a maltose ou o controle, apenas com sacarose (Yancheva \& Roichev, 2005).
Castro et al. (2010), na indução da embriogênese somática em tecidos de laranja doce, concluíram que a glicose não foi eficiente na formação de calos embriogênicos, sendo as melhores fontes de carboidratos a maltose, seguida pela lactose, nas concentrações de 37 e 75 mM. Embriogênese somática não foi observada nos meios de cultura contendo galactose, glicose ou sorbitol para nenhuma cultivar estudada.

Em cacau foi observada a formação de embriões em meios contendo glicose, frutose e sacarose, enquanto que em explantes cultivados continuamente em maltose ou sorbitol não foi observada a produção de embriões somáticos (Traore \& Guiltinan, 2006).

$\mathrm{O}$ efeito de vários carboidratos também foi testado na indução de embriogênese somática em Hevea brasiliensis. A sacarose foi substituída por maltose, frutose ou glicose e a produção de embriões somáticos foi significativamente maior em meio contendo maltose e em tempo menor do que o necessário com sacarose (Blanc et al., 1999).

Para a pupunha, os protocolos de embriogênese somática desenvolvidos utilizam sacarose como fonte de carboidrato (Almeida \& Almeida, 2006; Steinmacher et al., 2007a, 2007b, 2007c).

A resposta a determinado carboidrato é dependente da espécie ou mesmo linhagem celular. No entanto, a sacarose é o sacarídeo mais utilizado na cultura de tecidos vegetais e mesmo na embriogênese somática. A determinação da melhor fonte de carboidrato é complexa, uma vez que os açúcares desempenham várias funções durante a embriogênese somática. Nas plantas os açúcares, normalmente, são fonte de carbono e energia, na osmolaridade, tem função na proteção contra estresses e ainda são moléculas sinalizadoras (Lipavská \& Konrádová, 2004). Os carboidratos podem ainda agir como agentes morfogênicos, fornecendo informação posicional para a maquinaria celular relacionada ao desenvolvimento (Pien et al., 2001; Rolland et al., 2002). Estudos já demonstraram que a atividade mitótica está relacionada com os gradientes de carboidratos na planta (Borisjuk et al., 1998) e que a atividade da expressão de ciclinas em Arabidopsis é regulada por diferentes tipos de açúcares (Riou-Khamlichi et al., 2000), o que pode explicar, em parte, a resposta favorável de um carboidrato em detrimento dos demais na indução de calogênese em tecidos vegetais. 
A sacarose é total ou parcialmente hidrolisada em frutose e glicose. O metabolismo da sacarose ocorre intracelularmente e a enzima invertase é responsável por sua hidrólise (George et al., 2008). Apesar da rápida hidrólise, acredita-se que a sacarose tenha efeitos estimulatórios no desenvolvimento de embriões e alguns destes não possam ser substituídos pela glicose e frutose sozinhas, ou suas combinações (Taber et al., 1998; Iraqi \& Tremblay, 2001). No entanto, para a pupunha os resultados aqui obtidos demonstraram que a glicose é tão eficiente quanto a sacarose na indução de calos embriogênicos.

O manitol é um açúcar com seis moléculas de carbono e é a forma reduzida da manose 6-fostato, que pode ser convertido em frutose 6-fosfato, outro produto da hidrólise da sacarose. Apesar de ser de lenta absorção, é rapidamente metabolizado pelas plantas e pode estimular respostas fisiológicas e moleculares específicas, por agir como molécula sinalizadora. Este açúcar-álcool é o mais utilizado como agente osmótico para modificar o potencial de água, levando a estresse osmótico e podendo induzir a formação de embriões somáticos (George et al., 2008). No entanto, sua utilização como única fonte de carbono não induziu a formação de calos em pupunha e possivelmente a sua combinação com outro carboidrato, como a sacarose ou a glicose seja necessária para suprir a energia necessária.

Os embriões somáticos obtidos no meio de maturação (Figura 1a) foram transferidos para meio de conversão. Embora a porcentagem de calos com embriões somáticos tenha sido relativamente alta, foram observadas plantas anormais, tanto nos meios com sacarose, quanto com glicose (acima de 30\%). Apesar disso, plantas normais também foram obtidas, as quais foram transferidas para meio de multiplicação in vitro (Figura 1b).

\section{Referências}

Almeida, M. \& Almeida, C. V. Somatic embryogenesis and in vitro plant regeneration from pejibaye adult plant leaf primordia. Pesquisa Agropecuária Brasileira, v. 41, n. 9, p. 1449-1452, 2006. DOI: 10.1590/S0100-204X2006000900015.

Benkirane, H. et al. Somatic embryogenesis and plant regeneration from fragments of immature inflorescences and coleoptiles of durum wheat. Plant Cell, Tissue and Organ Culture v. 61, n. 2, p. 107-113, 2000. DOI: $10.1023 / \mathrm{A}: 1006464208686$.

Bensaad, Z. M. et al. Effects of cold pretreatment, carbohydrate source and gelling agents on somatic embryogenesis from anthers of Vitis vinifera L. cvs. 'Regina" and "Reichensteiner". Acta Horticulturae, v. 440, p. 504-509, 1996. DOI: 10.17660/ActaHortic.1996.440.88.
Blanc, G. et al. Effects of carbohydrate addition on the induction of somatic embryogenesis in Hevea brasiliensis. Plant Cell, Tissue and Organ Culture, v. 59, p. 103-112, 1999. DOI: 10.1023/A:1006437731011.

Borisjuk, N. et al. Calreticulin expression in plant cells: developmental regulation, tissue specificity and intracellular distribution. Planta, v. 206, n. 4, p. 504-514, 1998. DOI: 10.1007/s004250050427.

Buchanan, B. et al. Biochemistry and molecular biology of plants. Rockville: American Society of Plant Biologists, 2000. 1367 p.

Castro, L. M. et al. Embriogênese somática a partir de calos de cultivares de laranja doce. Ciência Rural v. 40, n. 8, p. 1831-1834, 2010. DOI: 10.1590/S0103-84782010000800026.

Delporte, F. et al. Plant regeneration through callus initiation from thin mature embryofragments of wheat. Plant Cell, Tissue and Organ Culture. v. 67, n. 1, p. 73-80, 2001. DOI: 10.1023/A:1011697316212.

George, E. F. et al. Plant propagation by tissue culture: the background. Dordrecht: Springer, 2008. 504 p.

Iraqi, D. \& Tremblay, F. M. The role of sucrose during maturation of black spruce (Picea mariana (Mill.) BSP) and white spruce (Picea glauca (Moench) Voss) somatic embryos. Physiologia Plantarum, v. 111, p. 381-388, 2001.

Jiménez, V. M. Involvement of plant hormones and plant growth regulators on in vitro somatic embryogenesis. Plant Growth Regulation, v. 47, n. 2-3, p. 91-110, 2005. DOI: 10.1007/s10725005-3478-x.

Lipavská, H. \& Konrádová, H. Somatic embryogenesis in conifers: the role of carbohydrate metabolism. In Vitro Cellular \& Developmental Biology: Plant, v. 40, n. 1, p. 23-30, 2004. DOI: 10.1079/IVP2003482.

Merkle, S. A. et al. Morphogenetic aspects of somatic embryogenesis. In: Thorpe, T. A(Ed.). In vitro embryogenesis in plants. Netherlands: Kluwer Academic Publishers, 1995. p. 155-203.

Mora-Urpí, J. El pejibaye (Bactris gasipaes H. B. K.): origem, biología floral y manejo agronómico. In: PALMERAS POCO UTILIZADAS DE AMÉRICA TROPICAL. 1984, Turrialba. Anais... Turrialba: FAO/CATIE, 1984. p. 118-160.

Morel, G. \& Wetmore, R. H. Fern callus tissue culture. American Journal of Botany, v. 38, n. 2, p. 141-143, 1951.

Murashige, T. \& Skoog, A. A revised medium for rapid growth and bio-assays with tobacco tissue cultures. Physiologia Plantarum, v. 15, n. 3, p. 473-497, 1962. DOI: 10.1111/j.1399-3054.1962. tb08052.x.

Pien, S. et al. Novel marker genes for early leaf development indicate spatial regulation of carbohydrate metabolism within the apical meristem. Plant Journal, v. 25, n. 6, p. 663-674, 2001.

Riou-Khamlichi, C. et al. Sugar control of the plant cell cycle: differential regulation of Arabidopsis D-type cyclin gene expression. Molecular Cellular Biology, v. 20, n. 13, p. 4513-4521, 2000.

Rolland, F. et al. Sugar sensing and signaling in plants. The Plant Cell, v. 14, p. S185-S205, 2002. DOI: 10.1105/tpc.010455. 
Silva, J. B. F. \& Clement, C. R. Wild pejibaye (Bactris gasipaes Kunth var. chichagui) in Southeastern Amazonia: pupunha brava (Bactris gasipaes Kunth var. chichagui) no sudeste da Amazônia. Acta Botanica Brasilica, v. 19 n. 2 p. 283-286, 2005. DOI: 10.1590/ S0102-33062005000200010.

Steinmacher, D. A. et al. Somatic embryogenesis from immature peach palm inflorescence explants: towards development of an efficient protocol. Plant Cell Tissue Organ Culture, v. 89, n. 1, p. 15-22, 2007a. DOI: 10.1007/s11240-007-9207-6.

Steinmacher, D. A. et al. Somatic embryogenesis from peach palm zygotic embryos. In Vitro Cellular \& Developmental Biology: Plant, v. 43, n. 2, p. 124-132, 2007b. DOI: 10.1007/s11627-0079032-y.

Steinmacher, D. A. et al. Somatic embryogenesis in peach palm using the thin cell layer technique: induction, morpho-histological aspects and AFLP analysis of somaclonal variation. Annals of Botany, v. 100, p. 699-709, 2007c. DOI: 10.1093/aob/mcm153.

Taber, R. P. et al. Kinetics of Douglas-fir (Pseudotsuga menziesii) somatic embryo development. Canadian Journal of Botany, v. 76, p. 863-871, 1998. DOI: 10.1139/b98-050.
Traore, A. \& Guiltinan, M. J. Effects of carbon source and explant type on somatic embryogenesis of four cacao genotypes. HortScience, v. 41, n. 3, p. 753-758, 2006.

Van, K. T. T. \& Lê, B. V. Current status of thin cell layer method for the induction of organogenesis or somatic embryogenesis in woody trees. In: Jain, S. M. et al. (Ed.). Somatic embryogenesis in woody plants. Netherlands: Kluwer Academic Publishers, 2000. v. 6. p. 51-92.

Villachica L., H. Cultivo del pijuayo (Bactris gasipaes Kunth) para palmito en la Amazonia. Lima: Tratado de Cooperacion Amazonica, 1996. 153 p.

Yancheva, S. D. \& Roichev, V. Carbohydrate source can influence the efficiency of somatic embryogenesis in seedless grapes (Vitis vinifera L.). Biotechnology \& Biotechnological Equipment, v. 19, n. 2, p. 62-66, 2005. DOI: 10.1080/13102818.2005.10817192. 
